\title{
FISSION PRODUCT CONTROL IN HTGR PLANTS
}

\author{
H. J. de Nordwa11, t W. E. Be11*
}

\begin{abstract}
Fission product control in a typical 2000 MW(t) HTGR plant is discussed in terms of (1) radiation dose guideIInes as established by the AEC, (2) fission product pathways to the environment, (3) Eission product distributions under normal and selected accident conditions, and (4) the physical models and basic data used to describe fisston product transport $S i x$ key fission product nuclides, namely

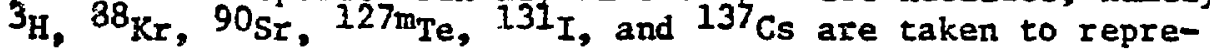
sent chemically and radiologically all significantly mobile flssion products.

Results of release calculations for the six nuclites show substantial margins (or safety factors) between acceptable (guideline) and predicted releases to the environment. For normal conditions, the smallest apparent margin, a bafety factor of 22 , is for $88_{\mathrm{Kr}}$. For acctdent conditions, the omallest apparent safety factor is 330 , which is for $90 \mathrm{Sr}$ in the design depregsurization accident.
\end{abstract}

\section{INTRODUCTION}

The goals of fission product control are minimization of radiation dose to man, optimization of equipment associated with the handing of fission products and description of the radiological corsequences of accldents $1 \pi$ which the normal barrlers between the fission products and the environment are breached.

Toak Ridge National Laboratory, Oak Ridge, Tennessee 37830. Operated by the UnIon Carbide Corporation for the U.S. Atomic Energy Commission. *

General Atomic Company, San Dlego, Californda 92138. 
Standards for acceptable radlation dosès to man alm at controlling the maximum dose commitmeat made by any individual and by the population as a whole. The current objective is to limit the maximum dose commitment rate from nuclear power to the whole body or any organ of any offsite Individual to about $5 \mathrm{mrem} / \mathrm{yr}$, which 15 a small fraction of the natural background of 100-250 mrem/yr. 1

Total population exposure from a given plant is currently determined by Integrating (dose $x$ population) over a 50 -mile radius. ${ }^{2}$ Integral dose rates of 10-30 man-rein per plant per year are befng projected for large reactors. This population dose does not include any allowance for doses recelved during unanticipated events such as accidents or the repair of major components.

Once in a lifetime maximum individual dose guidelines for use in accident analysis are established by reguiation ${ }^{3}$ as 25 rem to the whole body and $300 \mathrm{rem}$ to the thyrold. A bone dose guideline of $<150 \mathrm{rem}$ is being used in relation to the potential release of $90 \mathrm{Sr}$ during a fast depressurization. No population dose gulde for use in accident analysis has been defined numerically.

Practical and econonically acceptable goals for fission product control in large HTGR systems are currently being established. Foi?owing some quantification of these overall goals in terms of specific plant release goals the paths by which fission products can reach the environment and the status of methods for assessing fission product transport within an HTGR will be discussed.

While the emphasis in this paper will be on demonstrating that specific release goals can currently be met, it must be emphasized that if probable radiation cost in man-rem is vitimately to be assessed, best-value calculations and error assessments rather than the conservative estimstes accepted for licensing will ultimately be required.

\section{PLANT RELEASE GOALS}

The selection of a small set of nuclides to characterlze the behavior of radiologically important fission products in an HTGR has been described by Flowers. 4 Tritium has been added to the list.

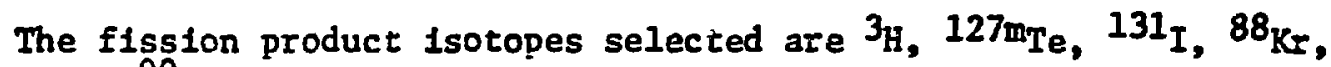
$137 \mathrm{Cs}$, and $90 \mathrm{Sr}$. Chemically this group represents all significantly mobile fission product elements. Satisfactory control of these six key fission products in an HTGR system means sat.sfactory control for all fission products. The 1ist has been restricted to one 1sotope per element for the sake of brevity.

Restrictions may be imposed for reasons other than radiological toxicity, for example, the release of stable and long-lived tellurium 


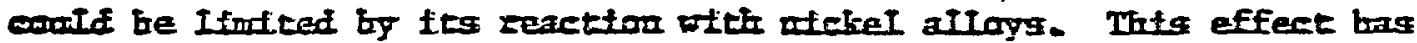

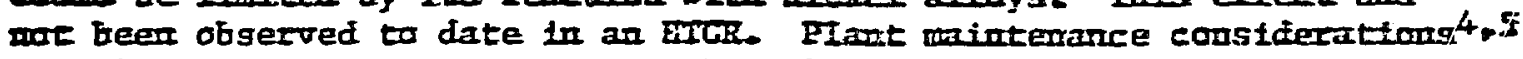
mix also lead to restrictions on the release of $\gamma$-emitters such aq I4 $0_{\mathrm{Ba}-\mathrm{La}}$ and ${ }^{137} \mathrm{Cs}$ from the core.

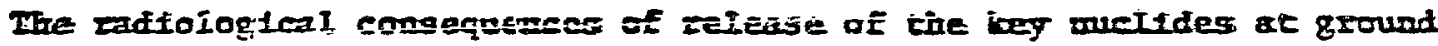
Ietrel on a hyputhetical site aze compared to Tables I and 2 under narmi anf acefdent conditions in terts of aren/gr received at the exinston azen Goundary (EAB)* per curle/jear released under mormal condltiors, and

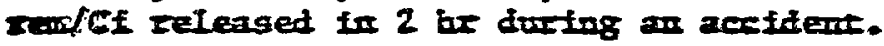

\section{FISSION ERODUCT PATHNAYS IO IHE ENVIRORREN}

The barrlers and stoks proudded in the HTGR to prevent fisston products from belng transported to the envircment from the fuel kernels where they are bord are shown in Fig. 1. The barriers and sinks within the PCRV Itner determine the radionuclide inventory th the primary circult; this irventory is inportanc because it is most readily avallable for release durfing accidents involving breaches of the prifary cooratment. Because of the siuggishness witi which hent and fission products are trassported in the core, it is unlikely that stgntficant relense of issston products from the core will occur during currenely analyzed aceidents. Conponents outside the PCPV Iner attenuate and/Cr contain radionaclides that leak from the PCRV.

The first and most important fission product bardier is the fuel particle coating, whose effectlveness depends upon materlal properties, service temperature, and fission product half-life and aconic number. Under normal operating temperature, SiC coutings provice an absoluce barrler for ali íssion product3; pyrocarboz coatings provlde a selective barfler, whict is impermeabie to gases and iodine and nore or less permeable to metals. In escaping fros the fuel rod, which is the next larger core structural unit, a iission product turst pass tirough the fuel rod artix and across a helium-filled gap between the fuel rod and the fuel element structural graphite. Both the matrix and graphite contain large surface areas upon which less volatile fission products ean adsorb, but the effectivecess of the matrix as a diffusion barrier (ar delay) is gifotitzed by the horogeneous distribution of fuel within It and lts higher operating temperaruze. The structural graphite does however provide an effective diffusion delay for metallic elssion products, again depending on half-life, atoulc number and temperature. Structural graphite has iltele ef fect on gas transport on account of its high permeability.

Within the primary circuit, the purification plant and the valls of the syasem serve as sinks for fission products, their effectiveness

Federal regulations define an exclusion aren vishin which access is controlled by the zenctor operacor. 3 
Tabla 1. Dose Complement Rate per Unit Releaso Uader Normal Conditiong

Releave Rate - I Cl/yr at ground level

$$
x / Q-1 \times 10^{-5} \mathrm{sec} / \mathrm{m}^{3}
$$

Concentration at EAs $=3.175 \times 10^{-13} \mathrm{C1} / \mathrm{m}^{3}$

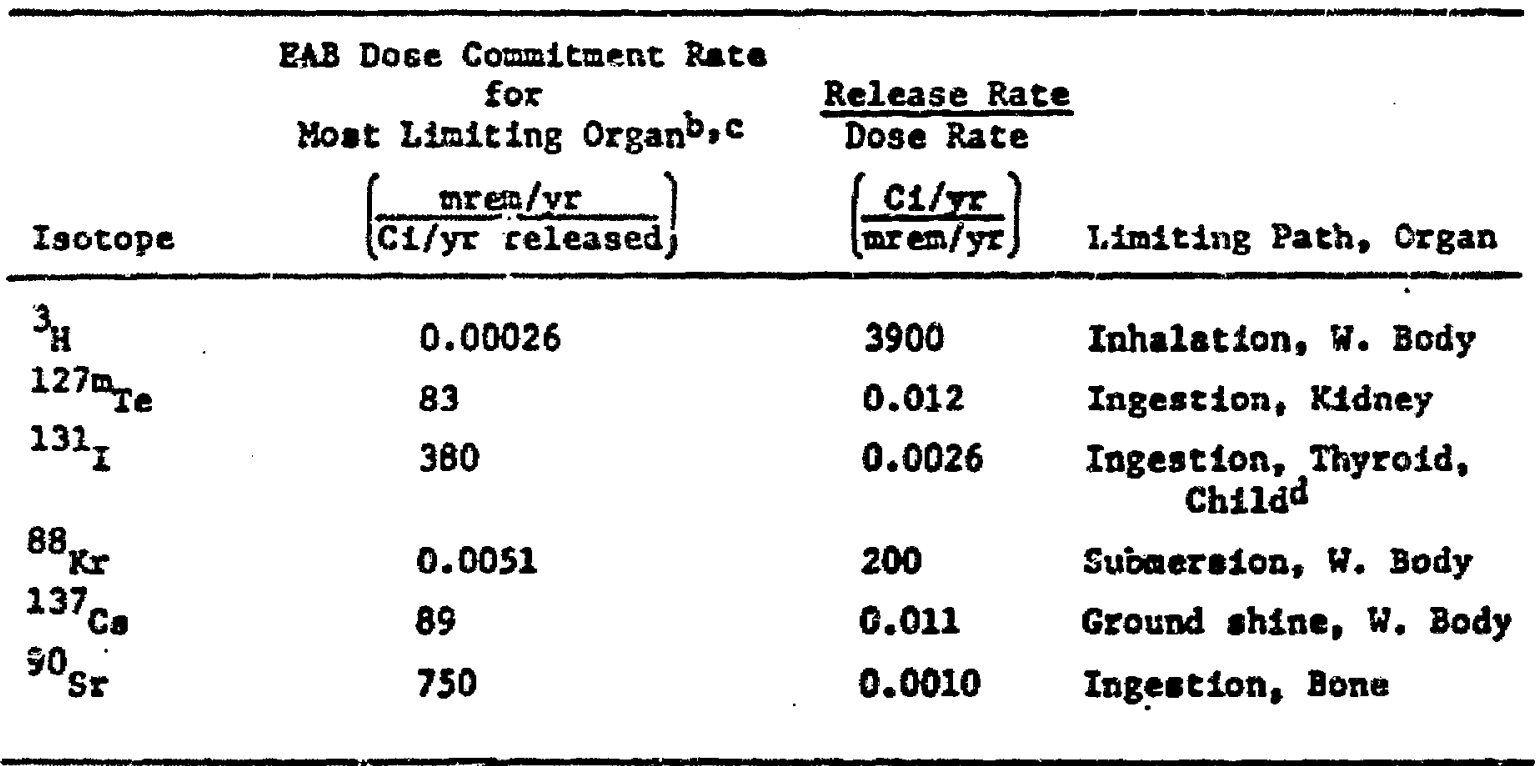

EAB - Exclusion Area Boundary.

Oorgan dose in dose vio subrersion, ground radiation, Inhalacton, and Irigiestion.

CDose factors fron Ref. 6. Ingestion path dose factors are divided by 3 -ince no one 18 assumed to grow more than $1 / 3$ of his food. Doge facrors from Ref. 7. Ingestion path dose facror to adjugted. 
Table 2. DAE Dose Comitment per Jnit Release During an Accident Activity keleased to Atmosphere $=1 \mathrm{Cl}^{\mathrm{a}}$

$$
X / Q=1 \times 10^{-3} \mathrm{sec} / \mathrm{m}^{3}
$$

\begin{tabular}{|c|c|c|c|c|c|}
\hline \multirow[b]{2}{*}{ Inotope } & \multicolumn{3}{|c|}{$\begin{array}{l}\text { Dose Combltwent } \\
\text { (rem/C1 released) }\end{array}$} & \multirow{2}{*}{$\begin{array}{l}\text { C.. to Exceed } \\
\text { Lefitting }{ }^{b} \text { Dose }\end{array}$} & \multirow[b]{2}{*}{ LImitlng Organ, Path } \\
\hline & H. Body & Thyroid & Bone & & \\
\hline \multirow{3}{*}{$\begin{array}{l}{ }_{\mathrm{H}} \\
127 \mathrm{~m} \\
132\end{array}$} & 0.00038 & 0.00038 & 0.00038 & 66,000 & W. Body, Inhalation \\
\hline & 0.00057 & $0.029 c$ & 0.0043 & & Kidney, Limit undefined \\
\hline & 0.0010 & 0.51 & 0.0010 & 590 & Thyrold, Inhalation \\
\hline & 0.00050 & 0.00050 & 0.00050 & 50,000 & W. Body, Submerston \\
\hline${ }^{7} \mathrm{Ce}$ & 0.011 & 0.011 & 0.021 & 2,300 & ค. Body, Inhalation \\
\hline ST & 0.45 & 0.45 & 6.8 & 22 & Bone, Inhalation \\
\hline • & & & & $\cdot$ & $\cdot$ \\
\hline
\end{tabular}

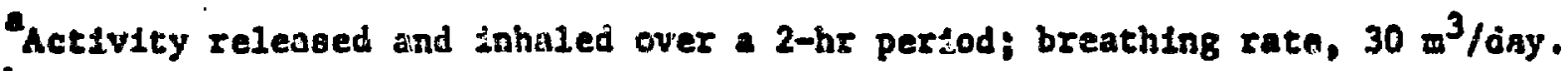
Thio is not a working 1imit.

Cedoey pathway. 


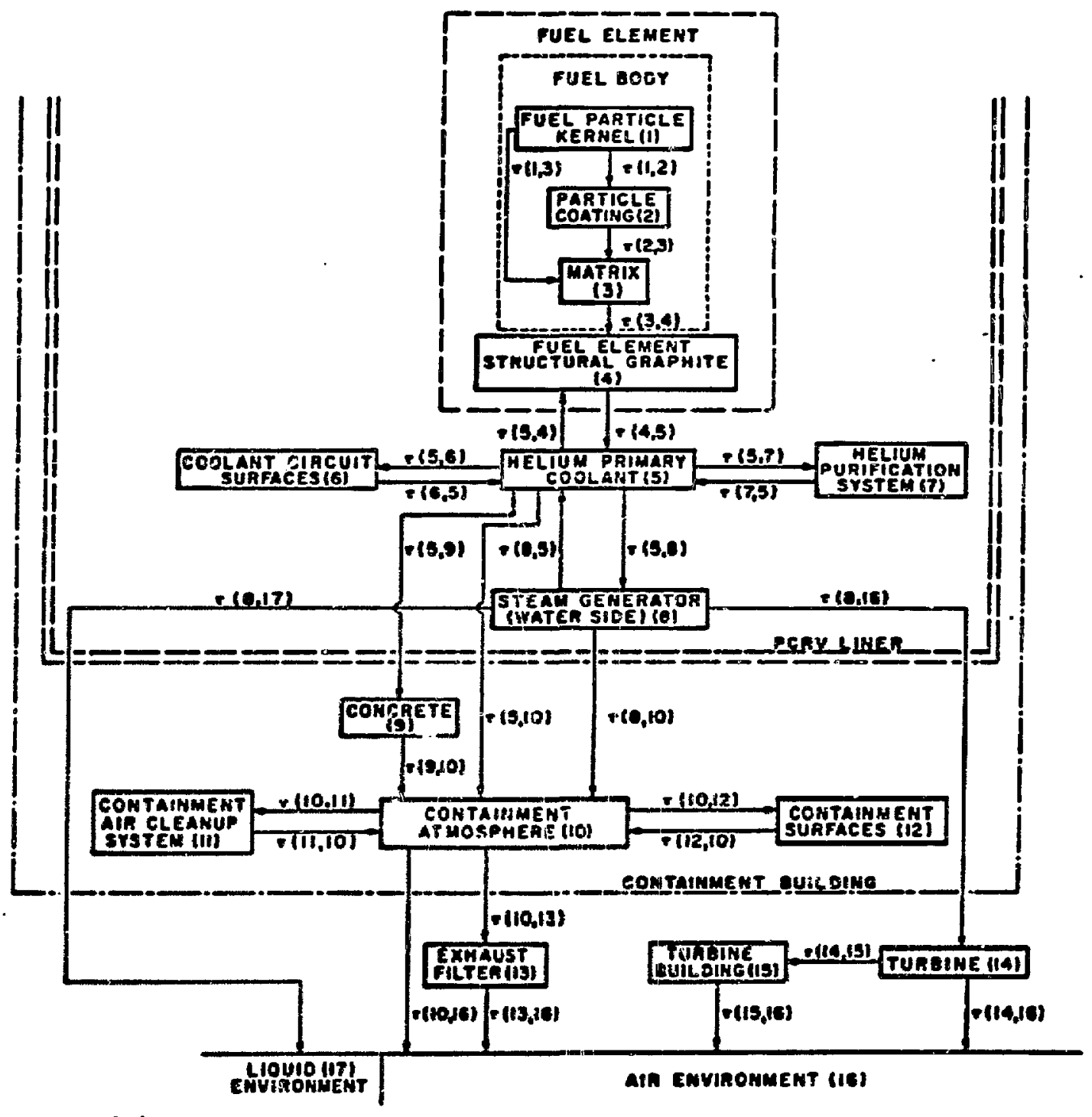

HTGR STSTEM COMPONENTS CONTROLLING FISSION PRODUCY TRANSPORT TO ENVIRONAENT 


$$
\therefore \because \quad \cdots \because
$$

F1g. 1. HTGR System Components Controlling F1881on Product Transport to Environment. 
depending on fission product half-11fe, volatility, and chemical reactivity. The coolant circult surfaces can become a source of fission products during certain accidents, as Indicated by the double arrows in Fig. 1.

Pathways for fission products to reach the enviroment under normal operating conditions are (i) leakage of prinary coolant through the PCRV IIner $[(\tau(5,9)$ and $\tau(5,10)]$ and (2) leakage of primary coolant into the reheater sections of the steam generators $[\tau(5,8)]$. (The steam pressure In the reheaters is lower than the hellum coolant pressure.) Accidents Involving large increases in both these leakage paths are analyzed in HTGR oafety reviews. The concrete wail of the PCRV and the water in the cooler parts of the secondary coolant system function as sinks for elemental lodine and less volatile metallic fission products passing through them.

Fission products reaching the containment are controlled by (1) the containment air cleanup system, (2) deposition on containment surfaces, (3) filtration of alr leaving the contalnment, or (4) decay. During accldents involving release of primary cpolant into the secondary containment, ventilation is stopped, isolation ralves are closed, and leakage from the secondary containment $[\tau(10,16)]$ becomes the dominant path to the atmosphere.

Flosion products reaching the secondary coolant (water side of the steam generazor) can reach the enviroument elther as 11quids, or gas via the steam air ejector $[\tau(14,16)]$. . Trltf.um is unique in that it can reach the environment via diffusion through the sieam generator tube walls as well as via the pathways open to the nuble gases. It therefore appears In both liquid and gaseous effluents.

\section{CURRENT FISSION PRODUCT DISTRIBUTION ESTIMATES FOR NORMAL AND ACCIDENT SITUATIONS}

This section sumarizes and discusses the results of fission product release and distribution calculations made for a typical $2000 \mathrm{MN}(t)$ HTGR using the plant paramel:ers taken from the Preliminary Safety Analysis Report 8 (Table 3 ). Fission product distributions under normal conditions and following three accidents involving breach of the primary containment are considered. The physical models used to represent fission product tzansport and the paranseter values used in these models are discussed later In Section 5 .

Table 4 summarizes the expected fission product distribution under normal confitions at the end of reactor life. Inspection of Table 4 permits some important conclustons to be drawn:

1. The Inventory of fission products closest to the environment Is well controlled by the graphite core and the particle coatings. (See also ref. 9.)

2. Only small fractions of the radiologically toxic elements, lodine and strontium, remain gas-borne in the primary circult, and hence are able to be transported by gas leaks through the PCRV Iiner. 
Table 3. Plant Parameters Used in Fission Product: Transport Calculations

PrImary Coolant Purification Rate

PCRV Leak Rate

Reheater Leak Rate

Contalnment - Atm Purification Rate During Accident

- Recirculation Filter Efficiency

$\mathrm{I}, \mathrm{Cs}, \mathrm{Sr}$

Organic Iodide

Containment Leak Rate During Accident (first 24 hr)
$5.3 /$ day

(5.01\%/day

$0.001 \% / d a y$

$1 \mathrm{vol} / \mathrm{hr}^{\mathrm{a}}$

907

$30 \%$

$0.5 \% /$ day

apurification starts 1 hr after accident. 
Table 4. Predicted Normal Fission Product Distributions in a 2000-MW(t) $\operatorname{HTGR}^{\dot{a}^{2}}$

\begin{tabular}{|c|c|c|c|c|c|}
\hline Isotope & $\begin{array}{l}\text { Equilibxium } \\
\text { Core Inventory } \\
\text { (C1) }\end{array}$ & $\begin{array}{c}\text { Primary } \\
\text { Iriventory } \\
\text { CI } \\
\text { ges-borne }\end{array}$ & 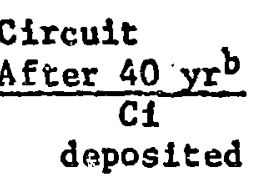 & $\begin{array}{l}\text { Rate of Gaseous } \\
\text { Release to } \\
\text { Environment } \\
(C 1 / y r)\end{array}$ & $\begin{array}{c}E E A B \\
\text { Concentration } \\
\left(\mathrm{C} 1 / \mathrm{m}^{3}\right)\end{array}$ \\
\hline${ }^{3} \mathrm{H}$ & $1.7 \times 10^{4}$ & 1.9 & 0 & 48 & $1.5 \times 10^{-11}$ \\
\hline${ }_{131_{I}}^{127 \mathrm{~m}_{\mathrm{Te}}}$ & $\begin{array}{l}1.5 \times 10^{6} \\
6.0 \times 10^{7}\end{array}$ & $\begin{array}{l}5.6 \times 10^{-4} \\
8.5 \times 10^{-2}\end{array}$ & $\begin{array}{l}6.8 \times 10^{2} \\
8.6 \times 10^{3}\end{array}$ & $\begin{array}{l}1.6 \times 10^{-7} \\
2.5 \times 10^{-5}\end{array}$ & $\begin{array}{l}3.0 \times 10^{-20} \\
7.7 \times 10^{-18}\end{array}$ \\
\hline${ }^{88} \mathrm{Kr}$ & $1.0 \times 10^{8}$ & $2.3 \times 10^{3}$ & 0 & 45 & $1.4 \times 10^{-11}$ \\
\hline${ }^{137} \mathrm{Cs}$ & $4.1 \times 10^{6}$ & $.1 .7 \times 10^{-4}$ & $1.1 \times 10^{4}$ & $6.2 \times 10^{-8}$ & $2.0 \times 10^{-20}$ \\
\hline${ }^{90} \mathrm{Sr}$ & $4.3 \times 10^{6}$ & $4.1 \times 10^{-5}$ & $2.7 \times 10^{3}$ & $1.5 \times 10^{-8}$ & $4.8 \times 10^{-21}$ \\
\hline
\end{tabular}

${ }^{a} x / Q=10^{-5} \mathrm{sec} / \mathrm{m}^{3}$ as in Table 1 
3. There are considerable margins between the reference release limits ( $\mathrm{C} 1 / \mathrm{yr} / \mathrm{mrem} / \mathrm{yr}$ ) 11sted in Table 1 and the releases to the environment ( $\mathrm{C} 1 / \mathrm{Yr}$ ) in Table 4.

4. While the projected release of cestum to the environment is clearly accepiable, the preserce of $\sim 11,000 \mathrm{Cl}$ of ${ }^{137} \mathrm{Cs}$ in the primary cizcuit musi be considered in terms of the contribution it could make to the toral man-rem dose dellvered by an HTGR if major maintenance such as removal of a steam generator were necessary.

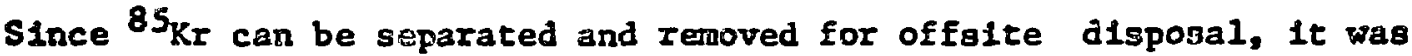
not considered in assessing the radiological impact of the plant.

Table 5 summarizes the 2-hr activity release to the environment following a design basis depressurization accident involving a penetration fallure with $100 \mathrm{in.} 2$ flow area. In this accident, the containment is 1solated by closing of lsolation valves, and activity release to the enviroment occurs by leakage from the containment.

Table 6 sumarlzes the actlvity release to the environment resulting from a single steam tube rupture in the reheat section of a steam generator. In this accldent, activity monltors detect radloactivit $y$ in a reheat line, the defective reheater is isolated, and the loop is shut down. Release to the atwosphere is via the steam air ejector.

The third accident Involves steam leakage into the primary coolant oystem with concurrent fallure of the molsture monitor. It is assumed that the steam leak is not isolated quickly and the leaking loop is not: dumped automatically. As the leak continues, the pressure rellef valve opens, once due to the Inttial pressure buildup, and again as a result of steam-carbon reactlons. Some Elssion products are released as a result of reaction of stean with core graphite and falled fuel particles. The radiologlcal consequences of this accident are less severe than for the design basis depressurization accident.

Let us now consider the estimates of releases during the first $2 \mathrm{hr}$ of these accidents in conjunction with the plant release limits in Table 2. Again substantlal margins appear to exist; in fact some margins are larger in the accident case because the release limits are higher and the contalnment is 1solated except for an assumed leak rate. This Is true in spite of the additional safety factor of 10 applied to the primary circult inventory for use in accident analyses.

Some of these margins are large enough to permit design changes without significant effect on potential radiological impact. For example, If one were not limited by requirements relating to access to the primary circult one could use only pyrocarbon coated fuels. One also has considerable tolerance (on the same basis) toward undetected releases of metallic fission products from partially or completely blocked coolant channels. Alternately one does not need to be so concerned about the 
Table 5. Estimated Activity Release (2-hr) to the Fnvironment Following a Design Basis Depressurization Accident

\begin{tabular}{|c|c|c|c|c|}
\hline \multirow[b]{2}{*}{ Isotope } & \multirow[b]{2}{*}{$\begin{array}{c}\text { Release to } \\
\text { Containment } \\
\text { (CI) }\end{array}$} & \multicolumn{2}{|c|}{ Containment Inventory after $2 \mathrm{hr}$} & \multirow{2}{*}{$\begin{array}{l}\text { Two-hr } \\
\text { Release to } \\
\text { Atmosphere } \\
\text { (C1) }\end{array}$} \\
\hline & & $\begin{array}{c}\text { Circulating } \\
\text { (C1) }\end{array}$ & $\begin{array}{c}\text { In Cleanup System } \\
\text { Filter } \\
\text { (C1) }\end{array}$ & \\
\hline \multirow{3}{*}{$\begin{array}{l}{ }^{3} \mathrm{H} \\
127 \mathrm{~m} \\
131_{\mathrm{Te}}\end{array}$} & 19 & 19 & 0 & 0.008 \\
\hline & 74 & 33 & 41 & .0 .026 \\
\hline & 950 & 420 & 530 & 0.33 \\
\hline \multirow{3}{*}{$\begin{array}{l}{ }^{88_{\mathrm{Kr}}} \\
{ }^{137_{\mathrm{Cs}}} \\
{ }^{90}{ }_{\mathrm{Sr}}\end{array}$} & $2.3 \times 10^{4}$ & $1.3 \times 10^{4}$ & 0 & 7.4 \\
\hline & 59 & 24 & 35 & 0.020 \\
\hline & 190 & 76 & 110 & 0.067 \\
\hline
\end{tabular}


Table 6. Estinated Activity Release to Environment After a Reheater Tube Accldent

\begin{tabular}{ll}
\hline Isctope & Reiease to Environment (Ci) \\
\hline $3_{\mathrm{H}}$ & 0.037 \\
$127 \mathrm{~m}_{\mathrm{Te}}$ & $1.1 \times 10^{-6}$ \\
${ }^{131_{\mathrm{I}}}$ & $1.6 \times 10^{-4}$ \\
$88_{\mathrm{Kr}}$ & 44 \\
${ }^{137} \mathrm{Ca}$ & $3.2 \times 10^{-7}$ \\
$90_{\mathrm{Sr}}$ & $7.9 \times 10^{-8}$ \\
\hline
\end{tabular}


fraction of a deposited fission product that could re-enter the gas phase during an accident $[\tau(6,5)]$. In the accidents Ifsted In iables 5 and 6 , $100 \%$ of the primary circuit inventory of lodine, cesium, and strontium could be released to the isolated containment without exceeding dose Iimits.

However since the ${ }^{88} \mathrm{Kr}$ margin is relatively small, increases in core temperature in response to pressure for higher thermal efficiency can caly be made if accompanied by corresponding improvenents in fuel quality and fallure rates.

It is also apparent from scaling the doses per curle entering the containment, that the containment is capable of holding substantial fractions of the core inventorles of the more volatile nuclides such as lodins, krypton, tritium, and cesium.

In view of the reliance placed upon the contalnment, one should ask what the consequences of fallure to close the 1solation valve would be. Using current re-entrainment factors $[\tau(6,5)]$, depressurization without containment would lead to dose guidelines being exceeded if the "accident (X10)" primary circult inventory were used; if the expected (normal) inventory were used, one would not expect to exceed the IImits.

Using Information similar to that reviewed in Section 5, the radiological impact of a $2000 \mathrm{NW}(t)$ HTGR may be calculated for all fission products, not fust the six reference nuclides. Taking into account all fission products does not significantly alter the conclusion that there are substantial margins between acceptable and predicted releases, particularly under accident conditions.

\section{CURRENT BASIS OF FISSION PRODUCT DISTRIBUTION ESTDLATES \\ -}

Assessment of the radiological consequences of ITGR pperation and accldents revolves around a description or the amounts and mobilities of fission products in the primary coolant circuit. This section will indicate how these quantities are currently estimated for the reference elements. For brevity. Individual gteps in the fission product path will be identifled by the $\tau$ in $F$ ig. 1 . For example $\tau(M, 5,6)$ means the transport of 1sotope or element $M$ from a capacitance (5) to capacitance (6).

\subsection{Noble Gases}

It is now well established that the coatings of HTGR fuel particles are, for practical purposes, impermeable to krypton and xenon; therefore $\tau\left(K_{r} 2,3\right)$ and $\tau(X e 2,3)$ are zero. Cas release is thus a sign of coating fallure or contamination of the outer coatings by uranium or thorium and is represented by $T(1,3)$ in FIg. 1 . For newly manufactured particles $\tau(1,3)$ is the sum of contributions from imperfect, damaged and contaminated 
particles and is determined experimentally by weasuring the steady state release $(R / B)^{\star}$ of $85 m_{K r}$ on a sample of production fuel rods. Fort $S t$. Vrain specifications required $R / B(850 \mathrm{~K})$ to be $<3 \times 10^{-5}$ at $1100^{\circ} \mathrm{C}$, a value which was achieved.

The percentage of falled fuel is expected to be $<17$ at fu12 burnup and fast neutron exposure for both fuel types (BISO fertile and IRISO f1ssile). Mathematical models are used to determine the core-average fuel fallure-fraction, whici is currenty $0.27 \%$. The release gf krypton and xenon from falled fuel has been measured. A recent study $10^{2}$ indicated $85 \mathrm{~m}_{\mathrm{K}} \mathrm{R} / \mathrm{B}$ value of $5 \times 10^{-3^{\circ}}$ at $1100^{\circ} \mathrm{C}$ for failed particles.

Experiments have demonstrated repeatedly shat the steady-state release

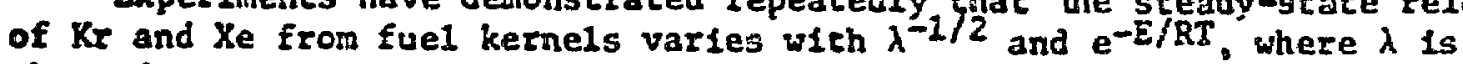
the radioactive decay constant and $E$ is an activacion energy characteristic of the release process. At 10 cemperatures (< $500^{\circ} \mathrm{C}$ ). diffustonal release tends to become zero and fission recoll controls release. 10 at nomal fuel temperatures $\left(700\right.$ to $\left.1200^{\circ} \mathrm{C}\right)$, E $1.3-23 \mathrm{kcal} / \mathrm{mole}$, which is a relatively low value, suggesting a diffusion process more rapid than bulk difiusion. At temperatures above $1300^{\circ} \mathrm{C}, \mathrm{E}$ is higher, suggesting some contribution from bulk diffusion. The same activation energy applies to both intact and falled particleg in fuel rods. On the basis of experimental results, xenon release is taken to be $-1 / 2$ that of a krypton 1sotope of the same half-life. Values $O f R / B$ and $E$ are lese well defined for fuel at very high burnup, and $\mathrm{E}$ may cont Inue to increase above $1200^{\circ} \mathrm{C}$.

In calculating clrculating gas lnventorles, a factor of 4 increase 18 explicitly applied to the rererence fission gas release (R/B) data for particles faling in service. This increase allows for the potential Increase in gas release fallowting hydrolygis or oxidation of the kernel cy Impurities in the coolant or following carburization by interaction of oxide kernels with carbon. The reference $R / B$ data for as-manufactured rods are reduced by a factor of 2.5 to account for the actual fuel temperature distribution, which ylelds an average temperature of $880^{\circ} \mathrm{C}$. The contribution frow particles with failed coatings is not similariy reduced since the potential for particle coating faliure is greater at higher temperature and the average temperature for fuel fafled in service may therefore differ from that of all fuel. The $R / B$ value for $85 \mathrm{Kr}$, and other long-lived gases, is assumed to be 1.0 for falled fuel particles. In-pile tests of protosype fuel for large HTGRs indicate that the release paraineters used in the above procedure are well-grounded. Fort St. Vrain 13 expected to finaliy validate this analysis.

Given rates of release from the fuel, the primary circult inventory corresponding to an equilibrium coro lo readlly calculated since krypton

\footnotetext{
$\mathrm{R} / \mathrm{B}-\frac{\text { release rate }}{\mathrm{b} \text { irch rate }}$ at steady otate.
} 
and xenon do: or the walls. 3.

Noble $\varepsilon$ environmen: ment are dela boxic shortaccidents gi.. for an assur.:

The tra: the noble $5:$ oeposit on :

It has about the $:$. halflife. $1 \%$, may be used : conservativc.

Iodine through fue: fully under: for lodine :experiments graphite wo: . raken.

The gas." primary clrcu tion rate of weakly adsor the circuit.

The rat circuit invi the Peach $\mathrm{Z:}$ The capacit. the prima:: of lodine $z$ : exist yet. reduces the: of the Drazof their $1 \mathrm{c}$. In service; as regards : purged cor.
Interact significantly with the core seructural graphite slant purification and leakage rates are gives in Table

leaving the PCRV $v 1$ a roule $\tau(5,8)$ are assured to reach the it delay; gases passing through the ventilated containan average of 120 minutes, long enough for the more gases to decay to Ellterable soild daughters. During .atering the secondary containment are retained, except akage rate frow the containment.

\subsection{Iodine and Tellurium}

t behavior of iodine and tellurium differs from that of : that lodine sorbs to some extent on graphice and can ct with oteel, concrete and other surfaces.11, 12,13

:ound that lodine Isotopes are released from fuels at -e or nore slowly than xenon 1sotopes of comparable herefore the equarions and parameters used for renon odine. A similar assumption for teliurium is even more

eilurium have been observed to be delayed in passing int sleeves below $900^{\circ} \mathrm{c}^{15}$ although the reasons are not Published adsorption 16 and diffusion coefficlents 17 shlte are too small to explain the delay. Adsorption y low concentrations where metallic impurities in the :ome significant may permit credit for delay to be

2 concentrations of lodine and lodine compounds in the re determined by the release rate of lodine, the defos1:e, the purification rate, and the rate of formation of - olatile compounds such as $\mathrm{CH}_{3} \mathrm{I}$ in the cooler parts of

Seposition currentiy used in calculating the primary in Table 4 is $40 \%$ per pass, based on observations in eactor, 19 and the General Atomic in-pile loop (GAIL) .20 2 avallable surface and the distribution of lodine in - cannot be calculated accurately since a complete set on isotherms for all the materlals present does not s at ORNL Indicate that oxidation of a metal surface zy of the surface for lodine. 21 The observed capacity exchangers could be unrepresentative, partly because cature $\left(200^{\circ} \mathrm{C}\right)$ and partly because of thetr short time F the Peach Bottom steam generators would be realistic zure, but the minute amounts of iodine released by a at the lodine loading in the steam generators is trivial 
compared with the fodine loading in the steam generators of a 1arge HTGR after 40 years.18,22 Examination of the behavior of the AVR sream generator could asgist in resoluing this uncertainty.

Currently, the capacity of the primary coolant system for lodine is assumed to be sufficient for the average deposition race to jemain constant over reactor I1fe. However, even if this were not so, exchange between long-itved and stable lodines on the steam generator and 131 I in the coolant could reduce the partial pressure of $131_{I}$ substantially at the and of life. 23

During accidents, the opposite processes of evaporation and the re-entrainment of surface dust deposits must be considered. Evaporation of lodine in the absence of steam is slower than the assumed rate of dust re-entrainment which is $1 \%$ under design bas1s depressurization conditions. The re-entrainment value of $1 \%$ is based on experiments 24 which showed that $<0.5 \%$ of the lodine could be blown off with particulates. Steam is assumed to have no effect on the partition of lodine between surfaces and the coolant. Account is taken of fission product releage resulting from hydrolysis of exposed fuel and oxidation of graphice. Factors relating to the adsorption and desorption of lodine are still being investigated.

Since the seals of the PCRV penetrations are purged with clean heliur, all lodine leaving the PCRV under normal conditions is assumed to elther pass through concrete $[\tau(5,9)]$ or the turbine $[\tau(5,8)]$. The decontamination factors applied in these regions for all lodine species are: passage through PCRV wall, 100; condensation of steam, 2000; and evaporation at cooling-tower temperature, 100. Iodine leaving the containment in ventilation air is not asgumed to be further attenuated except for decay In the containment. Some lodine will undoubtediy deposit on surfaces in the contalnment, and a further fraction may be converted to an organic form. 25 During an accident, containment alr 18 assumed to be purifled with $90 \%$ efficlency for (Lodine) and $30 \%$ for organic specles.

\subsection{Metal11c Fission Products}

Cegium and strontium Interact strongly witil graphite and metallic ourfaces at all HTGR temperatures and are able to form compounds with Impurities in the coolant.

Cesium and strontium do not permeate silicon carbide at normal temperatures. TRISO particles having cracked SIC coatings and Intact pyrolytic carbon coatings will behave like BISO coatings.

The release of ceslum from BISO coated particles is however a complex process not readily described in terms of diffusion theory. 26 Laboratory experiments show that if the concentrations of fission products are not too high (corresponding to < 10\% burnup in uranla kernels), thorla kernels 
can retain up to 907 of cesium aven at $1600^{\circ} \mathrm{C} .27$ In-plle confirmetion of this behavior is belng sought.

In the maantime, diffusion through the coatings is assumed to be rate-determining. The diffuston coefficients used represent a synthesis of the work of groups at ORNL 9,26 and GAC.10 $\mathrm{D}_{\mathrm{Cg}_{8}}$ in pyrocarbon is atrongly dependent on temperature and coating structure; the effects of fast neutron exposise lie within experimental uncertainty.

In calculating the Inventories reported In Table 4 end-ofmlife cealum release was set at $1 \%$ for all TRISO fuel aqual to the falled fuel fraction, and $10 \%$ for BISO particles.

For strontium, a similar situation obtalns for $\mathrm{ThO}_{2}$ kernels and release has been conservatively set at $50 \%$.

The fluxes of cestun and strontium from fuel rod to graphite are influenced by sorption $\mathrm{cn}$ the adjacent fuel rod matrix and graphite materials. At equilibrium, this may be described by a partition coefflelent or sorption raslo $(\phi)^{\star}$ which may be computed from vapor pressure versus composition c'rves for the matrix and graphite involved. Measurements indicate shat matrix-type materlals, compared to fuel element graphite, will sorb up to 50 times more cestum and strontium on a volume basis. 23 Like the vapor pressures, the partition coefficients are etructure and irradiation sensitive. However, the temperature-sensitivity of the vapor pressure curves is not reflected fully in $\phi$ since the heats of adsorption are not strongly temperature dependent.

Some consideration has been given to the possibility that equilibrium across the gap between fuel rod and graphite may not be reached as a result of the very low pressure (and hence mass cransfer coefficlent) so use of an equilibrium based $\phi$ may be unduly conservative. 29 Data from operating fuel elements are needed. In calculating the primary circuit Inventorles In Table $4, \phi_{\mathrm{Cs}}$ and $\phi_{\mathrm{Sr}}$ were taken to be 50 and 20 , respectively, on a volume basis.

The ratios of $\tau(4,5)$ to $\tau(3,4)$ for cesium and strontium are determined by the vapor pressures of the metals at the graphite-helium interface and their rate of transport through the grapinte. Though this graphite is cooler than the fuel coating and - 100 times thicker, it is considerably more porous. Those spectes able to move as vapors will therefore move much faster than in pyrocarbon, particularly if there is a permeation flow of heifim in the same direction; 30,31 those species whose transport Involves movement on internal surfaces or within crystallites will be

${ }_{\phi}-\frac{\text { conc. of metal in fuel matrix }}{\text { conc. of metal in graphice }}$ 
more effectively delayed though $D$ is known to increase at higher concentrations. Hellum flow and graphite structure sensitivity are greater for cesium than for strontium. Transport of the two metals through graphite as a result of helium flow through the graphite is currently assumed to be unimportant in comparison with condensed phase transport on the basis that the diffusion coefficients used are adequately conservative.

Metal vapor pressures over graphite generally exh1bit Freundlichtype adsorption behavior except at low concentration. Vapor pressure varies logarithmically with concentration as well as temperature. At low concentrations, a trangition fron Freundilch sorption behavior to Langmuir behavior occurs. 32 The latter is characterized by a constant heat of adsorption and a linear dependence of vapor pressure on concentration. The vapor pressure data currently used are represented by the Preundilch-type equationss

$$
\ln P_{S r}-\left[8.65-\frac{36,000}{T}\right]+\left[\frac{45,900}{T}-0.57\right] \ln C_{S r}
$$

and

$$
\ln P_{C_{8}}=\left[28.4-\frac{56,000}{T}\right]+\left[\frac{31,700}{T}-19.0\right] \ln C_{C B}
$$

where $C$ is in $\mu$ moles $/ \mathrm{m}^{2}, P$ is $\mathrm{in}$ atm, and $T$ is ${ }^{\circ} \mathrm{K}$. The average specific surface area of graphite is about $1 \mathrm{~m}^{2} / \mathrm{g}$; that for matrix graphite is much higher. Transition from Freundlich to Langmulr behavior has been observed in the case of the cestum-graphize system at approximately 0.2 umole $\mathrm{Cs} / \mathrm{m}^{2} \mathrm{C}$. For other metal-graphite systems, LangmuII behavior is assumed to begin at the lowest experimentally deternined vapor pressure. Theoretically computed corrections are applied to allow for the presence of other elements that may block adsorption sites. 33

Transport through the graphite is described by applying Fick's law as If graphite were a homogeneous isotropic solid. Release from the fuel and $\phi$ constitute the inner boundary conditions; evaporation through a gaseous boundary layer controls the flux at the outer boundary. The reference diffusion coefficients used are

$$
\begin{aligned}
& D_{C_{B}}=0.368 \mathrm{e}^{-39,000 / R T} \\
& D_{S T}=299 \mathrm{e}^{-60,000 / R T}
\end{aligned}
$$

where $D$ is $1 \mathrm{in} \mathrm{cm}^{2} / \mathrm{sec}^{8}, 34$

These diffusion coefficlents lead one to predict that only small fractions of the strontium released from the fuel reach the coolant; for cestum one has to rely more heaviiy upon retention by the fuel. For the accidents considered in the PSAR, the diffusion coefficlents are too small to permit any significant quantities of metallic fission products from being released from the core, even if fuel were to fall. 35 
It is recognized that the present representation of transport through the structural graphite may oversimplify a very complex process. Refinement is being sought experimentally and through experiments in the Peach Bottom HTGR.

In the primary circult, strontium is expected to adhere upon impact to surfaces $<750^{\circ} \mathrm{C}$ with unit efficiency, based upon experimental data obtalned in loops. 36 A somewhat lower deposition efficiency is found for cestum above $600^{\circ} \mathrm{C} .37$ Surface capacity for aetallic flssion products depends upon the presence of oxide films and dusty deposits; however in this Instance, as distinct from the situation with lodine, oxidation is beneficlal and there are presently no reservations about capacity. 38

There 1s, however, uncertainty about the behavior of deposited metals during depressurization accldents, since it is difficult to model reentrainment of small fractions of deposited dust under reactor conditions. On the other hand, because of the large margins between acceptable and predicted releases, it is not necessary to assume low re-entrainment fractions during a iepressurization in which the secondary containment system works. It may ba sufficlent to point out observations that suggest that concern about re-entrainment is being overemphasizea. Steep axial gradients of surface activity have been maintained for several million coolant cycles in loop and reactor systems in which strontium and cestum concentrations exceeded those of their precursors.37 Even in the Peach Bottom reactor, where dust from the steam generator has been shown to play a part in ceslum transport in the gas duct further downstream, the redistribution of cesium on a per pass basis was trivial.10 Cesium and strontium are also expected to transfer, at least partlally, from carton dust to surface oxide films ${ }^{39}$ or even to dissolve in base metals at high .. enough temperatures. 40 Finally, prolonged cooking is expected to make dust, as distinct from fission products, adhere more efiectively to surfaces. Further information on re-entralment is expected from the planned Peach Bottom HTGR post-power generation program and parallel laboratory Investigations.

The ratio (metal in soolant)/(metal on surfaces) for ceslum and gtrontium nuclides has been found to be very much smaller than for lodine In loops and reactors. 18,37 Therefore, the value of $40 \%$ plateout per pase used in calculating the primary circuit circulating activicy appears to be quite conservative for ceslum and strontium.

Cesium and strontium are assumed to be removed from hellum leaking through the PCRV wall with the same efficlency as lodine.

\subsection{Tritiun}

The principal sources of critiun in HTGR systems are ternary fission and neutron activation of (1) He-3 present in the heliun coolant, (2) Li- 6 and L1-7 present as impurtites in the core and reflector materials, and (3) B-10 in the control rods and reflector materials. Other tritiumproducing reactions are relactvely unimportant. The tritium production rate in a typlcal $2000 \mathrm{sin}(\mathrm{t}) \mathrm{HTGR}$ is about $12,000 \mathrm{cl} / \mathrm{yr}$. 
The release of tritfim from the fuel elements, control rods, and burnable poison rods is currently treated by assuming that the tritium from falled fuel particles, LI-6 in the graphite, and B-10 in the control paterial is all released into the helium coolant. Tritium behavior has been recently reviewed. 41

Some work has been done by $\mathrm{GAC}^{42}$ on the retention of exitium by fuel kernels and coated particles. The results of this work generally indicate that tritium is retained in intact coated particles at normal operating temperatures and that the retention decreases rapidly with increasing temperature. S1licon carblde coatings appear to be more retentive of tritium than are pyrocarbon coatings.

Trftium produced from he-3 can also be retained by core materlals (elther by exchange or sorption), but the capacity of the graphite is unienown. 43 Appreclable retention of triefum born in control materials is also indicated. Confirmation is required.

Tritium is currently assumed to diffuse through steam generator walls at a rate of $48 \mathrm{Cl} /$ year, based upon scaling of observations made at Peach Bottom. Tritium entering the secondary coolant system will be divided between the gas and liquid waste systems, somewhat at the operator's option. Gaseous release would ultimately be as water vapors containing HTO and a very amall fraction as $\mathrm{HT}$.

During an accident, tritium in the primary and secondary coolant ayotems could be released, depending on whe a rupture occurred. No tritium from the core is assumed to be lost at that time. Condensation of 8 tram in the containment vessel reduces the gas-borne ${ }^{3}$ H concentration.

\section{CONCLUSIONS}

1. The inventory of fission products in the primazy circuit to well controlled by the graphite core and particle coatings.

2. The $2000 \mathrm{MW}(t)$ HTGR has substantlal margins between calculated fission product releases and guideline releases established by the AEC. For normal conditions, the smallest margin, a safety factor of 22 , is for $88_{\mathrm{Kr}}$. The predicted $88_{\mathrm{Kr}}$ release $1 \mathrm{~s} 45 \mathrm{CI}$ and the guideline release $1 \mathrm{~s}$ $1000 \mathrm{Cl}$ (based on a whole-body dose at the site boundary and the AEC guideline of $5 \mathrm{mrem} / \mathrm{yr}$ ). For accident conditions, the smallest safety factor 1s 330 , which occurs for $90 \mathrm{Sr}$ in the design basis depressurizacion accident. The predicted $90 \mathrm{Sr}$ release in this accident $1 \mathrm{~s} 0.067 \mathrm{CI}$ and the guideline release is $22 \mathrm{Cl}$ (based on a bone dose guideline of $150 \mathrm{rem}$ ).

3. The mathematical models and parameters used in computing the primary circuit inventory, which can be regarded as the source of fission products during accidents and nomal operation are currently chosen to yield conservative margins. However, In view of the complexity of some of the phenomena involved, verification of margins by survelliance and additional R\&D are clearly desirable. 
4. The pressures of HTGR development are in the direction of higher helium outlet and core temperatures and therefore tend to decrease avallable margins. If the apparently high safety marging of HTGR are to be maintained in advanced systems, not only improved fuels but more precisely defined fiesion product trangfer functions will be needed.

5. While the projected release of ${ }^{137} \mathrm{Ce}$ 18 acceptable from a safety standpoint, the presence of this and other condensable gama-emitting 1sotopes in the primary circult must be considered from the standpoint of plart maintenance.

\section{Acknowledgement}

The authors wish to express thelr gratitude to the many contributors to this paper. 


\section{REFERENCES}

1. The Safety of Nuclear Power Reactors (Light Water-Cooled) and Related Fac1litles, USAEC Report WASH-1250 (July 1973), pp. 4-35.

2. The Safety of Nuclear Power Reactors (Light Water-Cooled) and Related Far.ilities, USAEC Report WASH-1250 (July 1973), pp. 4-25.

3. Code cf Federal Regulations, Titie 10, Part 100.

4. R. H. Flowers, p. 311 in Proceedings of the Gas-Cooled Reactor Information Meeting, Apri1 27-30, 1970, CONF-700401, Sponsored by Oak Ridge National Laboratory, Oak RIdge, Tenn.

5. R. H. Flowers, "Fission Product Control in the HTR," Paper 23 presented at the BNES International Conference on Nuclear Fuel Performance, London, England, October 15-19, 1973 (Proceedings to be published).

6. C. E. Easterly et al., Draft Environmental Impact Statement on LMFBR Program - Radiological Impact Assessment (unpublished work).

7. Final Environmental Statement Concerning Proposed Rule Making Action: Vol. 2, Analyt1cal Models and Calculations, USAEC Report WASH-1258 (July 1973).

8. Delmarva Power \& Iight Co., Sumit Power Station, Preliminary Safety Analys is Report, Docket \#50450 (1973).

9. J. O. Kolb, F. F. Dyer, and W. J. Martin, "Fission Product Behavior In the Coolant Circuit of the Peach Bottom HTGR," p. 172 in GasCooled Reactor Programs Ann. Prog. Rept., Dec. 31, 1972, ORNL-4911 (March 1974).

10. R. D. Burnette, W. E. Bell, and N. L. Baldwin, "Fission Product Retention Characteristics of HTGR Fuel," Proc. Brit. Nucl. Energy Soc., Conf. on Nuclear Fuel Performance, London, Oct. 1973.

11. P. E. Brown and H. J. de Nordwal1, Post Irradiation Radiochorical Analysis of Charge 8 for Pluto Loop A, AERE-R5040 or D.P. Report 388 (1965).

12. C. E. Milstead, W. E. BelI, and J. H. Norman, Nuc1. App1. Tech. I., 361 (1969).

13. R. D. Burnette, General Atomic Company, (unpublished work).

14. P. R. Rowland, W. E. Browning, and M. Carlyle, "Behavior of Iodine in an HTGR Cooling Circuit," Control of Iodine in the Nuclear Industry, Tech. Kep. 148, IAEA, 1973, p. 57. 
15. P. E. Brown, H. J. de Nordwa11, and I. Dosud11, Post-1rradiation Radiochemical Analys is of Charges $V$ and VI of Pluto Loop A,

AERE-R4856 or D.P. Report 341, (1965).

16. F. J. Salzano, Carbon 2. 73 (1964).

17. T. Mukaibo, Chem. Soc. Jap. Bull. 36, 629 (1963).

18. H. J. de Nordwall et a1., Paper 18, "An Intertm Report on Fission Product Release During Operation of the Second Peach Bottom Core," presented at the BNES International Conference on Nuclear Fuel Performance, London, 0ct. 15-19, 1973 (Proceedings to be pub11shed).

19. 40 MW(e) Prototype HTGR Post-construct1on R\&D Progress Report, GA-9237 (1969). (See aiso Ref. 8.)

20. D. D. Busch, The Nature of Condensible Fission Products in an HTGR Environment, GA-6957 (1966).

21. E. Hoinkis and M. F. Osborne, ORNL (unpub11shed work).

22. E. L. Compere, ORNL (unpublished work).

23. 330 MW (e) HTGR Research and Development Program, Quarterly Progress Report. GA-8270 (1967).

24. R. D. Burnette, GAC (unpublished work).

25. A. K. Postma and R. W. Zavadosk1, Review of Organic Iodide Formation under Acc1dent Conditions in Water-Cooled Reactors, WASH-1233 (Oct. 1972).

26. R. B. Evans III, Mathematical Descriotion of Fission Froduct Transport In Coated Particles during Post-1rradiation Anneals, ORNL-TM-4540 (to be published).

27. M. T. Horgan, Fission Product Release from Coated Particles Juring

- Post-1rradiation Anneais, ORNL-TM-4539 (to be published).

28. $330 \mathrm{MW}(\mathrm{e})$ HTGR Research and Deve iopment Program, Quarterly Progress Report, GA-8725 (1968).

29. J. R. Engel, ORNL (unpublished work).

30. M. N. Ozisik and M. D. Silverman, "The Effects of Transverse Flow on Fission Product Transport Through Graphite Tubes," Trans. Am. Nucl. Soc. 13,586 (1970).

31. R. B. Evans III, ORNL (unpublished work). 
32. C. E. M1lstead, Carbon 7, 199 (1969).

33. I. R. Zumwalt and M. J. Haire, Nucl. Sc1. Eng. 50, 91 (1973).

34. E. A. Bryant et a1., NucI. Sci. Eng. 15, 288 (1963).

35. S. H. Freld er al., Fission Product Release from an Overheated HTGR Fuel, ORNL-TM-2388 (1969).

36. G. E. Raines et al., Experimental and Theoretical Studies of Fission Product Deposition in Flowing Helium, BMI-1688 (1964).

37. H. J. de Nordwall et al., Post Irradiation Radlochemical Analysis of P1uto Loop 15, AERE-R5405 (1967).

38. C. E. Milstead and L. R. Zumwalt, Nuc1. Appl. 3, 495 (1967).

39. $330 \mathrm{MW}(\mathrm{e})$ HTGR Research and Development Program, Quarterly Progress Report, GA-8038 (1967) and GA-8600 (1968).

40. F. F. Dyer, ORNL (unpublishad work).

41. E. L. Compere, S. H. Freld, and C. W. Mestor, D1stribution and Release of Tritium in High-Temperature Gas-Cooled Reactors as a Function of Design, Operational, and Materlal Parameters, ORNL-TM4303 (in press).

42. HTGi Base Program Quarterly Progress Report for the Perlod Ending August 31, 1972, Gulf-GA-A12222 (Sept. 30, 1972), p. 1.

43. Win. B. Cottrell, ORNL Nuclear Safety Research and Development Program Bimonthly Report for March-Apr11 1972, ORNL-TM-3831 (July 1972), P. 79. 